\title{
PENDEKATAN METODE TAGUCHI PADA PERBAIKAN KUALITAS RASA KERUPUK (Studi Kasus: UKM Kerupuk ikan Ibu Chalim)
}

\author{
Septian Galang Ronaldi ${ }^{1}$, Deny Andesta ${ }^{2}$, Elly Ismiyah ${ }^{3}$ \\ ${ }^{1}$ Mahasiswa Teknik Industri, Fakultas Teknik, Universitas Muhammadiyah Gresik \\ ${ }^{2,3}$ Dosen Teknik Industri, Fakultas Teknik, Universitas Muhammadiyah Gresik Jl. Sumatera No. 101 \\ GKB-Gresik 61121, Jawa Timur, Indonesia \\ E-mail:galangronaldi@gmail.com
}

\begin{abstract}
Abstrak
UKM Kerupuk Ikan Ibu Chalim adalah sebuah UKM yang mengelolah sari ikan menjadi kerupuk ikan. UKM Kerupuk Ikan Ibu Chalim ini memerlukan perbaikan kualitas terhadap produk kerupuk ikan terutama pada respon rasa. Pada penelitian produk kerupuk ikan ini menggunakan pendekatan metode Taguchi. Adapun faktordan level yang digunakan sebagai berikut faktor Kaldu Ikan (A)(500gram, 530gram), Bawang Putih (B)(10gram, 13gram), Tepung Tapioka (C)(1000gram, 1100gram), Garam (D)(3gram, 4gram), Ketumbar (E)(3gram, 4gram), dan Penyedap Rasa (F)(4gram, 5gram). Pada eksperimen pembuatan produk kerupuk ikan ini menggunakan karakteristik kualitas Large The Better (LTB) dikarenakan semakin besar nilainya makan akan semakin baik. Uji yang digunakan untuk menentukan nilai dari kerupuk ikan adalah uji organoleptic. Orthogonal Array yang di gunakan adalah $\mathrm{L}_{8}\left(2^{7}\right)$ dengan menggunakan 8 eksperimen dan 2 kali replikasi. Setelah dilkukan eksperimen untuk perbaikan kualitas rasa pada produk kerupuk ikan ini maka diketahuifaktor yang berpengaruh terhadap rasa dri kerupuk ikan adalah Kaldu Ikan (A), Bawang Putih (B), Tepung Tapioka (C), dan Penyedap Rasa (F). akan tetapi ada faktor yang paling berpengaruh terhadap rasa dari produk kerupuk ikan adalah Kaldu Ikan (A).komposisi faktor dan level pembuatan kerupuk ikan adalah Kaldu Ikan (A)(530gram), Bawang Putih (B)(13gram), Tepung Tapioka(C)(1000gram), Garam (D)(4gram), Ketumbar (E)(3gram), dan Penyedap Rasa (F)(4gram).
\end{abstract}

Kata Kunci : Taguchi, Large The Better, Organoleptik.

\section{PENDAHULUAN}

Di era globalisasi yang semakin kompetitif ini, setiap palaku bisnis yang ingin memenangkan persaingan akan memberikan perhatian penuh pada mutu dan kualitas produk dan jasa. Dalan dunia industri, kualitas barang yang dihasilkan merupakan faktor yang sangat penting dan merupakan faktor kunci yang membawa keberhasilan usaha dalam meningkatkan posisi bersaing. Perhatian penuh terhadap kualitas akan memberikan dampak langsung kepada perusahaan, Sebagai contoh UKM kerupuk ikan Ibu Chalim yang mempunyai potensi untuk mengembangkan usahanya agar bisa lebih maju dibandingkan dengan UKM yang lain dikarenakan UKM kerupuk Ikan Ibu Chalim ini mempunyai ciri khas tersendiri terhadap rasa kerupuknya. UKM kerupuk ikan Ibu Chalim adalah salah satu industri yang mengelolah atau memproduksi kerupuk ikan. Dari keluhan konsumen yang paling tinggi berada pada rasa yang menghasilkan sebanyak 10 keluhan, warna dari kerupuk sebanyak 7 keluhan, kemampuan mengembang 5 keluhan, dan dengan, kerenyahannya sebanyak 4 keluhan. Dari beberapa keluhan yang di keluhkan oleh konsumen adalah kebanyakan dari rasa kerupuk ikan yang terkadang rasa dari kerupuk ikan UKM Ibu Chalim ini masih kurang terasa ikannya, kurang terasa penyedap rasanya, terkadang kurang terasa gurih dan terkadang terlalu asin. Adapun faktor-faktor dalam pembuatan kerupuk ikan adalah garam, penyedap rasa, ketumbar, bawang putih, dan kaldu ikan. Sedangkan komposisi pembuatan kerupuk saat ini adalah tepung tapioka sebanyak $1 \mathrm{~kg}$, garam sebanyak 3 gram, penyedap rasa sebanyak 4 gram, ketumbar sebanyak 3 gram, bawang putih sebanyak 10 gram, kaldu ikan sebanyak 500 gram, dan air sebanyak 500 mili liter. Oleh karena itu, perlu dilakukan usaha perbaikan kualitas kerupuk ikan dengan menggunakan metode taguchi agar pembuatan kerupuk bisa sesuai dengan selera konsumen.

\section{Tinjauan Pustaka 2.1 Kerupuk Ikan}

Menurut Sari (2013), Ikan mempunyai protein yang tinggi, dan kandungan lemaknya rendah sehingga banyak memberi manfaat kesehatan bagi tubuh manusia. Pengolahan ikan dengan berbagai cara dan rasa menyebabkan orang untuk mengelolah ikan dengan cara menjadikannya kerupuk ikan. Kerupuk ikan adalah kerupuk yang bahannya terdiri dari 
adonan tepung dan daging ikan. Jenis kerupuk lain yang banayak dijumpai adalah kerupuk udang yang tebuat dari adonan tepung dan udang. Kerupuk ikan atau kerupuk udang mempunyai beberapa kualitas tergantung pada komposisi banyaknya ikan atau udang yang terkandung didalam proses pembuatan kerupuk tersebut. Semakin banyak jumlah ikan atau udang yang di gunakan dalam proses pembuatannya maka semakin baik juga kualitasnya.

\subsection{Kualitas Menurut Taguchi}

Pengertian atau definisi kualitas dibagi dalam beberapa kategori yaitu berorientasi pada produk, berorientasi pada pengguna, berorientasi pada perusahaan, dan berorientasi pada nilai. Kualitas dalam hal yang lebih umum yaitu kemampuan produk yang digunakan. Serta kualitas sebagai pemenuhan kebutuhan atau spesifikasi (Desti, Wuryandari, Sudarno, 2014).

\subsection{Pengendalian Kualitas}

Menurut Ginanjar, Adianto, Susanty (2015), Pengendalian kualitas merupakan suatu rancangan dan strategi pengembangan yang digunakan untuk mengoptimalkan sebuah rancangan dari suatu produk, layanan,atau proses. Variabilitas dari suatu produk atau proses dapat direduksi melalui berbagai analisa optimasi dengan menggunakan perancangan eksperimen.

Pengendalian kualitas adalah penggunaan teknik-teknik dan aktivitas-aktivitas dalam upaya mencapai, mempertahankan dan memperbaiki kualitas dari suatu produk atau jasa (Desti, Wuryandari, Sudarno, 2014).

\subsection{On-line Quality Control}

Menurut Soejanto (2009), Rekayasa kualitas secara On-line merupakan suatu aktivitas untuk mengamati dan mengendalikan kualitas pada setiap proses produk secara langsung, aktivitas ini sangat penting dalam menjaga agar biaya produksi menjadi lebih rendah dan secara langsung dapat meningkatkan mutu dari sebuah produk.

\subsection{Desain Eksperimen}

Suatu desain eksperimen adalah evaluasi secara serentak terhadap dua atau lebih faktor (parameter) terhadap kemampuannya untuk mempengaruhi rata-rata atau variabilitas hasil gabungan dari karakteristik produk atau proses tertentu. Untuk mencapai hal ini secara efektif dan sesuai statistik, level dari faktor kontrol dibuat bervariasi, hasil dari kombinasi pengujian tertentu diamati, dan kumpulan hasil selengkapnya dianalisa untuk menentukan faktor-faktor yang berpengaruh dan tingkatan yang baik, dan apabilah peningkatan atau pengurangan tingkatan-tingkatan tersebut akan menghasilkan perbaikan yang lebih lanjut (Soejanto, 2009).

\subsection{Metode Taguchi}

Menurut Kurniawan, Sugianto, Yasin (2014), metode Taguchi merupakan suatu metode pengendalian kualitas sebelum proses berlangsung atau sering juga dinamakan offline quality control. Metode ini ditemukan oleh Dr. Genichi Taguchi dari Jepang. Taguchi menyertai filosofi yang baik untuk pengendalian kualitas dalam perindustrian. Tiga filosofi Taguchi:

1. Kualitas harus didesain ke dalam produk dan bukan hanya memeriksanya.

2. Kualitas yang baik dapat dijangkau dengan memperkecil deviasi dari sebuah target. Produk akan dirancang sehingga bebas dari faktor yang membuat tidak terkontrol.

3. Nilai dari kualitas harus diukur sebagai sebuah fungsi deviasi dari standar tertentu dan kerugian harus diukur pada seluruh sistem.

\subsection{Tahap Perencanaan Eksperimen}

Menurut Soejanto (2009), Desain eksperimen yang baik, apabila eksperimen yang dilakukan sesuai dengan masalahnya dan mempunyai efisiensi yang tinggi, yaitu apabila eksperimen dilakukan dengan menggunakan biaya, waktu dan usaha yang minimum tetapi dapat memberikan infoermasi hasil yang optimum.

\section{Metodologi Penelitian}

Langkah-langkah penelitian dan pengolahan data dapat digambarkan sebagai berikut: 


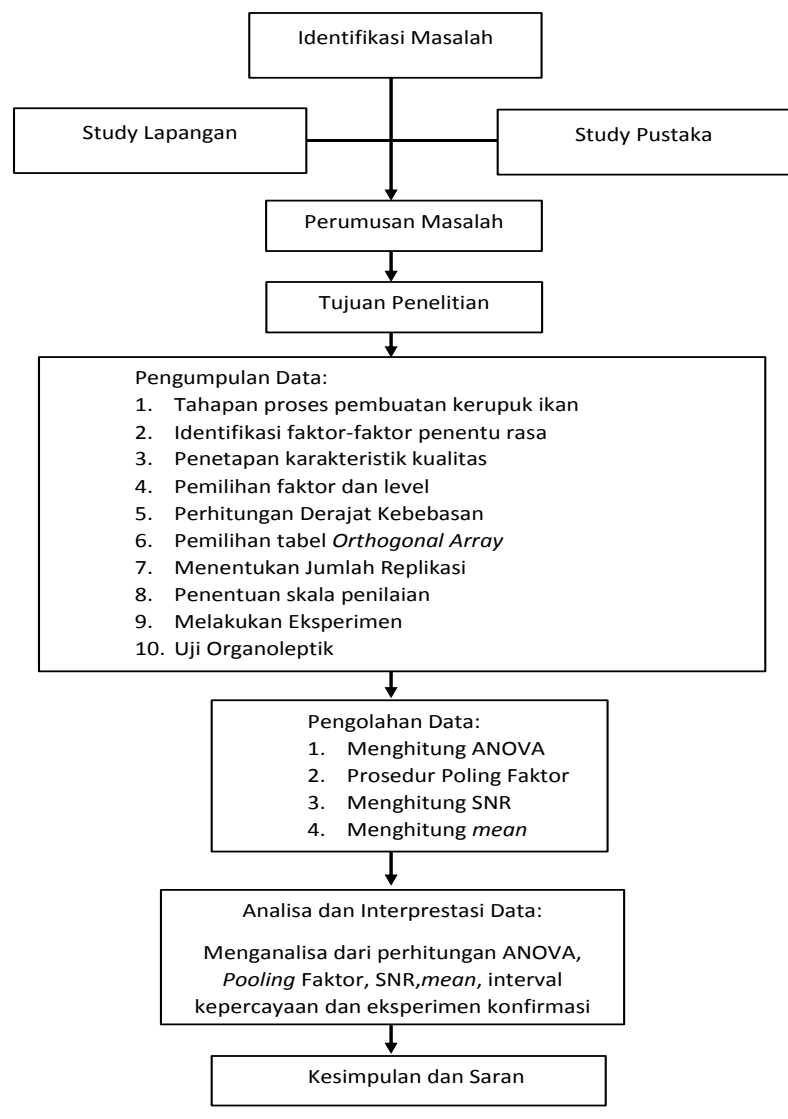

4. Hasil dan pembahasan

\subsection{Skala penilaian}

Skala penilaian ini digunakan untuk menilai output yaitu menggunakan skala Likert sesuai dengan tabel 5

Tabel 5 Skala Penilaian Output Rasa

\begin{tabular}{|c|l|}
\hline Nilai & Keterangan \\
\hline 1 & Tidak Enak \\
\hline 2 & Kurang Enak \\
\hline 3 & Cukup Enak \\
\hline 4 & Enak \\
\hline 5 & Sangat Enak \\
\hline
\end{tabular}

\subsection{Tahap Analisa Data}

\subsubsection{Menghitung Signal To Noise Rasio (SNR)}

Nilai Signal To Noise Rasio dari data dapat dilihat pada tabel 7
Tabel 7 nilai SNR

\begin{tabular}{|r|r|r|r|c|}
\hline No. & L8 & $\begin{array}{r}\boldsymbol{\mu} \\
\text { Re } \\
\text { plik } \\
\text { asi } \\
\mathbf{1}\end{array}$ & $\begin{array}{r}\boldsymbol{\mu} \\
\text { Rep } \\
\text { lika } \\
\text { si 2 }\end{array}$ & SNR \\
\hline 1. & 111111 & 3 & 2,8 & 9,2325 \\
\hline 2. & 111222 & 2,6 & 3 & 8,87696 \\
\hline 3. & 1221122 & 2,8 & 3,4 & 9,70535 \\
\hline 4. & 122211 & 2,8 & 3,6 & 9,89997 \\
\hline 5. & 2121212 & 3,2 & 3,2 & 10,10327 \\
\hline 6. & 2122121 & 3,4 & 3 & 10,05243 \\
\hline 7. & 2211221 & 3,8 & 4 & 11,81312 \\
\hline 8. & 2212112 & 4 & 4,2 & 12,24826 \\
\hline
\end{tabular}

\subsubsection{Menghitung Efek Faktor dari Signal to Noise Rasio (SNR)}

Hasil perhitungan efek faktor dari signal to noise rasio dapat dilihat pada tabel 8 sebagai berikut:

Tabel 8 Perhitungan Efek Faktor dari $S N$

\begin{tabular}{|c|c|c|c|c|c|c|}
\hline Level & A & B & C & D & E & F \\
\hline 1 & 9,428 & 9,566 & 10,542 & 10,213 & 10,309 & 10,371 \\
\hline 2 & 11,054 & 10,916 & 9,94 & 10,269 & 10,173 & 10,112 \\
\hline Delta & 1,654 & 1,35 & 0,603 & 0,056 & 0,137 & 0,259 \\
\hline Rank & 1 & 2 & 3 & 6 & 5 & 4 \\
\hline
\end{tabular}

(Sumber: Data Diolah Dengan Software Minitab 16, 2018)

Dapat disimpulkan bahwa Dari hasil tabel efek tiap faktor SN ratios diatas dapat dilihat bahwa faktor A (Kaldu Ikan) berada pada rangking pertama yang artinya bahwa faktor A adalah faktor yang paling berpengaruh terhadap respon rasa pada produk kerupuk ikan. Dari rata-rata tiap faktor dipilih paling besar untuk disarankan sebagai rancangan usulan sehingga didapatkan rancangan usulan A2, B2, C1, D1, E1, Dan F1 Adapun gambarnya dapatdilihat pada gambar 2 sebagai berikut: 


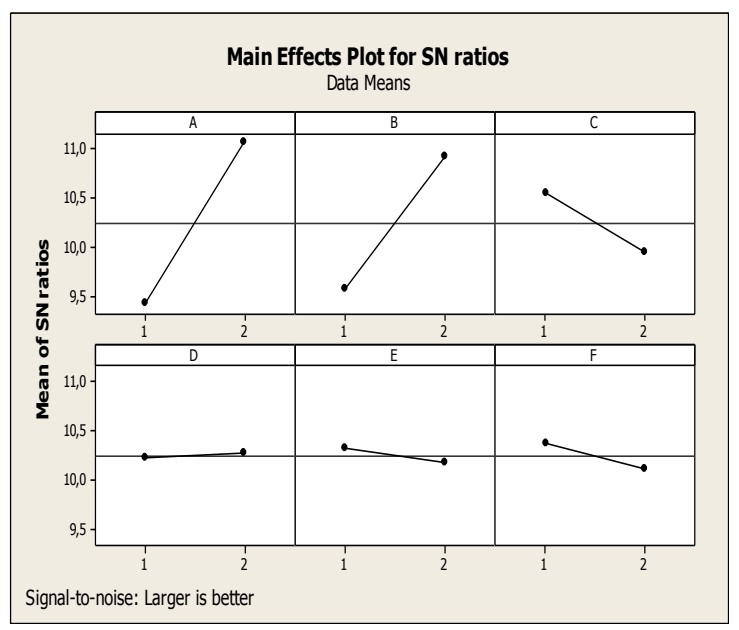

Gambar 2 Main Effects Plot for SN ratios (Sumber: Data Diolah Dengan Software Minitab 16, 2018)

Dari gambar tersebut juga dapat diketahui komposisi perbandingan faktor dan level yang dipilih untuk pembuatan kerupuk ikan berdasarkan respon rasa. Adapun faktor dan level yang dipilih dapat dilihat pada tabel 9 sebagai berikut:

Tabel 9 Faktor dan Level Yang Terpilih Skala Percobaan

\begin{tabular}{|c|c|c|}
\hline Faktor & Level & Keterangan \\
\hline A & 2 & 530 gram \\
\hline B & 2 & 13 gram \\
\hline C & 1 & 1000 gram \\
\hline D & 2 & 4 gram \\
\hline E & 1 & 3 gram \\
\hline F & 1 & 4 gram \\
\hline
\end{tabular}

\subsubsection{Menghitung Analysis Of Variance (ANOVA)}

Dari hasil perhitungan anova dapat dilihat pada tabel 10 sebagai berikut:

Tabel 10 Analisis Of Variance (ANOVA)

For Rasa, Using Adjusted SS For Tests

\begin{tabular}{|c|c|c|c|c|c|c|}
\hline Source & DF & SS & MS & Fhitung & Ftabel & P \\
\hline A & 1 & 5,28569 & 5,28569 & 10466,11 & 161,45 & 0,006 \\
\hline B & 1 & 3,64552 & 3,64552 & 7218,44 & 161,45 & 0,007 \\
\hline C & 1 & 0,72648 & 0,72648 & 1438,49 & 161,45 & 0,017 \\
\hline D & 1 & 0,00618 & 0,00618 & 12,23 & 161,45 & 0,117 \\
\hline E & 1 & 0,0373 & 0,0373 & 73,86 & 161,45 & 0,074 \\
\hline F & 1 & 0,13411 & 0,13411 & 265,56 & 161,45 & 0,039 \\
\hline Residual Error & 1 & 0,00051 & 0,00051 & & & \\
\hline Total & 7 & 9,83578 & & & & \\
\hline
\end{tabular}

(Sumber: Data Diolah Dengan Software Minitab 16, 2018)

Berdasarkan dari perhitungan hipotesa diatas dapat disimpulkan bahwa ada faktorfaktor yang berpengaruh terhadap respon rasa kerupuk ikan yaitu faktor kaldu ikan (A), bawang putih (B), tepung tapioka (C), dan penyedap rasa $(F)$. Hal ini terlihat bahwa nilai $p$-value kurang dari 0,05 atau jika menggunakan Ftabel lebih besar dari Fhitung maka, diartikan bahwa faktor tersebut berpengaruh terhadap respon rasa dan begitu juga sebaliknya. Jika Ftabel lebih kecil dari pada Fhitung maka, diartikan bahwa faktor itu tidak berpengaruh terhadap respon rasa pada produk krupuk ikan. Dapat di lihat dari perhitungan diatas bahwa faktor yang paling berpengaruh terhadap respon rasa yaitu faktor kaldu ikan (A) dikarenakan nilai Fhitungnya paling tinggi dari pada nilai faktor yang lainnya.

\subsubsection{Pooling Faktor}

Pooling faktor digunakan untuk mengidentifikasi faktor yang tidak signifikan dikumpulkan sebagai error di mulai dari faktor dengan jumlah kuadrat/sum of square (SS) tekecil sampai derajad bebas kesalahan sama dengan atau lebih setengah derajad bebas total. Adapun tabel pooling faktor dapat dilihat pada tabel 11

Tabel 11 Pooling Faktor

\begin{tabular}{|c|c|c|c|c|c|c|}
\hline Source & Pooling & DF & SS & MS & Fhitung & Ftabel \\
\hline A & & 1 & 5,28569 & 5,28569 & 10466,11 & 161,45 \\
\hline B & & 1 & 3,64552 & 3,64552 & 7218,44 & 161,45 \\
\hline C & & 1 & 0,72648 & 0,72648 & 1438,49 & 161,45 \\
\hline D & $y$ & & & & & \\
\hline E & $y$ & & & & & \\
\hline F & & 1 & 0,13411 & 0,13411 & 265,56 & 161,45 \\
\hline error & & 3 & 0,04399 & 0,14663 & & \\
\hline Total & & 7 & 9,83578 & & & \\
\hline
\end{tabular}

Dapat diketahui dari tabel 11 diatas bahwa faktor yang tidak signifikan adalah faktor D dan E, maka faktor D dan E di pooling up. Adapun perhitungannya sebagai berikut:

$$
\begin{aligned}
\text { SS }(\text { polled } \mathrm{e})=\mathrm{SSD}+\mathrm{SSE}+\mathrm{Sse} \\
=0,00618+0,0373 \quad+0,00051 \\
=0,04399 \\
\mathrm{DF}(\text { polled e }) \quad \mathrm{DFD}+\mathrm{DFE}+\mathrm{Dfe} \\
=1+1+1
\end{aligned}
$$




$$
\begin{aligned}
\operatorname{MS}(\text { polled e }) & =\frac{\text { SS }(\text { polled } e)}{\text { DF }(\text { polled })} \\
& =\frac{0,04399}{3} \\
& =0,14663
\end{aligned}
$$

\section{Kesimpulan}

Berdasarkan dari hasil pengolahan dan analisa data yang telah dilakukan pada bab sebelumnya, maka dapat diambil kesimpulan sebagai berikut:

1. Faktor yang paling berpengaruh terhadap respon rasa dari produk kerupuk ikan adalah faktor Kaldu Ikan (A) sebesar 530 gram, Bawang Putih (B) sebesar 13 gram, Tepung Tapioka (C) sebesar 1000 gram, Garam (D) sebesar 4 gram, Ketumbar (E) sebesar 3 gram, dan Penyedap Rasa (F) sebesar 4 gram. Dari beberapa faktor yang berpengaruh tersebut ada faktor yang paling berpengaruh terhadap respon rasa pada proses pembuatan produk kerupuk ikan yaitu faktor Kaldu Ikan (A).

2. Komposisi faktor dan level dalam pembuatan petis udang grade A terhadap respon rasa adalah $\mathrm{A} 2, \mathrm{~B} 2, \mathrm{C} 1, \mathrm{D} 2, \mathrm{E} 1$ dan F1.

\section{DAFTAR PUSTAKA}

Desti, Angga Saputra, Wuryandari, Triastuti, dan Sudarno. 2014. Penentuan Komposisi Waktu Optimal Produksi dengan Metode Taguchi (Studi kasus: Penelitian di pabrik kerupuk rambak stik cap ikan bawang, Semarang. Jurnal Gaussian Vol.3 no.1 hal. 11-20.

Ginanjar, geri, adianto, hari, Susanty, susy. 2015. Usulan kombinasi terbaik faktor yang berpengaruh pada pembuatan preform untuk mengurangi jumlah cacat dengan metode taguchi di PT. X. Jurnal online institut teknologi nasional. Vol.3 no. 2 ISSN: 2338-5081.

Isnanta, Mirza Firdiansah, Andesta, Deny, dahda, said salim. 2015. Penerapan metode taguchi pada proses fermentasi pupuk guano cair untuk menghasilkan kandungan yang optimal di ud pupuk guonoku. Jurnal Matrik vol.15 no.2 hal.59-68.

Kurniawan, cakra, sugito, hasbi yasin. 2014. Optimalisasi jumlah batu bata yang pecah menggunakan desain eksperimen taguchi (studi kasus: usaha batu bata bapak kholil ds. Bulak karangawen). Jurnal gaussian vol.3 no. 2 hal. 203-212.

Kurniawan, indra. 2010. Perancangan eksperimen untuk meningkatkan kualitas produk kerupuk palembang dengan menggunakan metode taguchi (studi kasus : usaha kecil dan menengah (ukm) dua saudara). Jurusan teknik industri Pekanbaru.

Sari, Eka Nila. 2013. Pembuatan kerupuk ikan bandeng dengan subtitusi subs duri ikan bandeng. Semarang.

Soejanto, irwan. 2009. Desain eksperimen dengan metode taguchi. Yogyakarta : graha ilmu.

Zayendra, siska, Yozza, hazmira, maiyastri. 2016. Penerapan metode taguchi untuk optimalisasi hasil produksi roti di usaha roti meyza bakery, padang sumatera barat. Jurnal matematika unand vol.5 no. 3 hal.122-130. 